\title{
Phenolic composition and biological activities of the in vitro cultured endangered Eryngium viviparum J. Gay
}

\author{
Manuel Ayuso ${ }^{\mathrm{a}, \mathrm{b}}$, José Pinela ${ }^{\mathrm{a}}$, Maria Inês Dias ${ }^{\mathrm{a}}$, Lillian Barros ${ }^{\mathrm{a}}$, Marija Ivanov ${ }^{\mathrm{c}}$, \\ Ricardo C. Calhelha ${ }^{\mathrm{a}}$, Marina Sokovićc ${ }^{\text {, Pablo Ramil-Rego }}{ }^{\mathrm{d}}$, M. Esther Barreal ${ }^{\mathrm{b}}$, \\ Pedro Pablo Gallego ${ }^{\mathrm{b}, *}$, Isabel C.F.R. Ferreira ${ }^{\mathrm{a}, *}$ \\ ${ }^{a}$ Centro de Investigação de Montanha (CIMO), Instituto Politécnico de Bragança, Campus de Santa Apolónia, 5300-253 Bragança, Portugal \\ ${ }^{\mathrm{b}}$ Applied Plant and Soil Biology, Faculty of Biology, University of Vigo, Campus Universitario, $s / n$. 36310 Vigo, Pontevedra, Spain \\ ${ }^{\mathrm{c}}$ Institute for Biological Research "Siniša Stanković"- National Institute of Republic of Serbia, University of Belgrade, Bulevar despota Stefana 142, Belgrade, Serbia \\ ${ }^{\mathrm{d}}$ GI-1934 TB-Biodiversity, IBADER, Campus Terra Universidad de Santiago, 27002 Lugo, Spain
}

\section{A R T I C L E I N F O}

\section{Keywords:}

Apiaceae

Herbal plants

Ex situ conservation

In vitro culture

Phenolic acids

Bioactive properties

\begin{abstract}
A B S T R A C T
Eryngium viviparum is an endangered species that requires management efforts based on complementary ex situ conservation strategies, such as in vitro culture. This study was carried out to evaluate the phenolic composition and the antioxidant, cytotoxic, and antimicrobial properties of $E$. viviparum aerial and root parts obtained by this micropropagation technique. The HPLC-DAD-ESI/MS ${ }^{\mathrm{n}}$ analysis showed that phenolic compounds were more abundant in the root $\left(102 \pm 4 \mathrm{mg} \mathrm{g}^{-1}\right.$ extract) than in the aerial part (40.6 $\pm 0.8 \mathrm{mg} \mathrm{g}^{-1}$ extract) of the plant. The major compound was trans rosmarinic acid, followed by trans 3 - $O$-caffeoylquinic acid. The root extract also showed higher antioxidant activity, with a result close to that of trolox in the thiobarbituric acid reactive substances (TBARS) formation inhibition assay, and a moderate toxicity to lung (NCI-H460), breast (MCF-7) and liver (HepG2) tumour cells. It was also more effective than ketoconazole against Penicillium ochrochloron. In turn, the aerial part extract inhibited Salmonella typhimurium more effectively than ampicillin. This study highlights $E$. viviparum as an unexplored source of bioactive compounds with potential application in the food, pharmaceutical, and other industrial sectors. Consequently, it promotes the interest of conserving this endangered species.
\end{abstract}

\section{Introduction}

Eryngium viviparum J. Gay (Fam. Apiaceae) is an endemic plant from the northwest of the Iberian Peninsula and France. Its current population is dramatically small and faces a high risk of extinction, being included in the International Union for Conservation of Nature's red list of threatened species since 2011 (Aguiar, 2003; Lansdown, 2011). To promote their protection, usual in situ conservation strategies have been implemented, such as management of wild populations and protection of natural habitats (Bañares et al., 2004). Currently, in Spain and Brittany (France), only policies based on in situ conservation are commonly used (Rascle et al., 2018; Romero et al., 2004). However, in some critical situations, it is necessary to resort to ex situ strategies such as in vitro plant tissue culture.

Micropropagation is an in vitro culture technique that allows the large-scale multiplication of plant species from excised plant parts within a short span of time, as well as for the storage and preservation of germplasm. The obtained in vitro-cultured plants (clones of the original mother plant) can be used in plant reintroduction programs and for research purposes, without damaging the existing populations (Ayuso et al., 2019; Engelmann, 2011; Sarasan et al., 2006). Plant tissue culture is also used to stimulate the synthesis and accumulation of secondary metabolites in the plant tissues, including alkaloids, terpenes, and phenolic compounds (Atanasov et al., 2015; Dias et al., 2016).

Several Eryngium species have been used in traditional medicine for the treatment of various human physiological disorders due to their bioactive chemical constituents. Aerial and root parts are used in the treatment of skin disorders and kidney stones, and to regulate arterial pressure (Wang et al., 2012). Infusions of these parts are also used to treat tapeworms and pinworms, digestive problems, and headache, and as a diuretic (Erdem et al., 2015; Vukic et al., 2018). Current research with plants of this genus has confirmed the presence of phytochemicals with pharmacological activities, specifically flavonoids and phenolic acids (Erdem et al., 2015; Wang et al., 2012), which have been reported as one of the main groups of phytochemicals with antioxidant,

\footnotetext{
* Corresponding authors.

E-mail addresses: pgallego@uvigo.es (P.P. Gallego), iferreira@ipb.pt (I.C.F.R. Ferreira).
} 
antimicrobial, and cytotoxic properties (Belkaid et al., 2006; Gugliucci and Bastos, 2009; Petersen and Simmonds, 2003).

Nowadays, the interest in natural and bio-based ingredients has increased due to the high market demand from the consumer and the food industry, among other sectors. However, the discovery of new bioactive compounds and the use of more sustainable sources at an industrial scale face some challenges related to the rational exploitation of natural resources and biodiversity (Atanasov et al., 2015; Lavergne et al., 2005; Li and Vederas, 2009). Although E. viviparum is a threatened species, the conditions for its germination and in vitro culture have already been established in recent studies (Ayuso et al., 2019, 2017); nevertheless, to the best of authors' knowledge, the phenolic profile and bioactive properties of this plant remain unknown. Therefore, this work was carried out to determine the composition in phenolic compounds and the antioxidant, antimicrobial, and cytotoxic activities of E. viviparum aerial and root parts obtained by in vitro culture.

\section{Material and methods}

\subsection{Plant material and in vitro culture}

Samples of E. viviparum were obtained from in vitro seed germination as formerly described by Ayuso et al. (2017). Briefly, the seedlings were cultured in MS basal medium, prepared as described by Murashige and Skoog (1962), supplemented with $0.1 \mathrm{mg} \mathrm{L}^{-1}$ indole-3-butyric acid, $3 \%$ sucrose $(w / v)$, and solidified with $1 \%$ agar $(w / v)$ at $\mathrm{pH} 5.8$. Cultures were incubated at $24 \pm 1{ }^{\circ} \mathrm{C}$ with photoperiod (16/8; light/ darkness). E. viviparum grows as a basal rosette and form shoot cluster on in vitro culture. Shoots clusters were divided into single shoots every 5 weeks and subculture to a fresh medium (Ayuso et al., 2019). The aerial parts and roots from fifth to eight subculture were collected and then freeze-dried (Telstar Cryodos, Telstar Industrial SL, Terrassa, Spain), reduced to powder, and stored at $-20^{\circ} \mathrm{C}$.

\subsection{Preparation of hydroethanolic extracts}

Samples $(\sim 1 \mathrm{~g})$ underwent to solid-liquid extraction twice with $80 \%$ ethanol $(30 \mathrm{~mL})$ for $1 \mathrm{~h}$ at $150 \mathrm{rpm}$ and room temperature, as described by Bessada et al. (2016). After filtration though Whatman paper No. 4, ethanol was separated under pressure in a rotary evaporator (Büchi R-210, Flawil, Switzerland) and the aqueous phase was freeze-dried.

\subsection{Analysis of phenolic compounds}

The extracts were re-dissolved in $20 \%$ ethanol at $5 \mathrm{mg} \mathrm{mL}^{-1}$ and filtered through $0.22 \mu \mathrm{m}$ syringe filters. The HPLC-DAD-ESI/MS ${ }^{\mathrm{n}}$ equipment and chromatographic conditions were formerly described by Bessada et al. (2016), as well as the identification and quantification procedures. Seven-level calibration curves $\left(25-800 \mu \mathrm{g} \mathrm{mL}^{-1}\right.$ for quercetin-3-O-glucoside and $2.5-80 \mu \mathrm{gL}^{-1}$ for the other standards were constructed for the standards rosmarinic acid $\mathrm{y}=$ $-652,903+191291 \mathrm{x} ; \quad r^{2}=0.999 ; \quad \mathrm{LOD}=0.15 \mu \mathrm{g} \quad \mathrm{mL}^{-1}$; $\mathrm{LOQ}=0.68 \mu \mathrm{gL}^{-1}$, chlorogenic acid $\mathrm{y}=-161,172+168823 \mathrm{x} ; r^{2}$ $=0.999 ; \mathrm{LOD}=0.20 \mu \mathrm{g} \mathrm{mL} \mathrm{m}^{-1} ; \mathrm{LOQ}=0.68 \mu \mathrm{g} \mathrm{mL} \mathrm{m}^{-1}$, caffeic acid $\mathrm{y}=406,369+388345 \mathrm{x} ; \quad r^{2}=0.994 ; \quad$ LOD $=0.78 \mu \mathrm{g} \quad \mathrm{mL}^{-1}$; $\mathrm{LOQ}=1.97 \mu \mathrm{g} \mathrm{mL}^{-1}$, ferulic acid $\mathrm{y}=-185,462+633126 \mathrm{x} ; r^{2}=$ $0.999 ; \mathrm{LOD}=0.20 \mu \mathrm{g} \mathrm{mL}^{-1}$; LOQ $=1.01 \mu \mathrm{g} \mathrm{mL}^{-1}$ ), and quercetin-3-Oglucoside $\mathrm{y}=-160,173+34843 \mathrm{x}, r^{2}=0.999 ; \mathrm{LOD}=0.21 \mu \mathrm{g} \mathrm{mL}{ }^{-1}$; $\mathrm{LOQ}=0.71 \mu \mathrm{g} \mathrm{mL} \mathrm{m}^{-1}$ ) and used in quantification. The results were expressed as $\mathrm{mg} / \mathrm{g}$ dry extract.

\subsection{Evaluation of biological activities}

\subsubsection{Antioxidant activity}

Two in vitro assays were performed to measure the extracts capacity to inhibit the formation of thiobarbituric acid reactive substances (TBARS) and the oxidative haemolysis (OxHLIA) as described by Lockowandt et al. (2019), using porcine brain cells and sheep erythrocytes as oxidizable subtracts, respectively. Trolox was the positive control. The results were given as $\mathrm{IC}_{50}$ values $\left(\mu \mathrm{g} \mathrm{mL}{ }^{-1}\right)(\Delta t$ of $30 \mathrm{~min}$ and 60 min were selected for the OxHLIA).

\subsubsection{Cytotoxic activity}

The extracts $\left(50-400 \mu \mathrm{g} \mathrm{mL} \mathrm{m}^{-1}\right.$ in ultrapure water) were tested against NCI-H460 (non-small cell lung carcinoma), MCF-7 (breast adenocarcinoma), HeLa (cervical carcinoma), and HepG2 (hepatocellular carcinoma) human tumour cells by the sulforhodamine B assay (Guimarães et al., 2013a). A non-tumour PLP2 cell line (porcine liver primary cells) was also tested to evaluate possible hepatotoxicity. Ellipticine was the positive control. The results were given as $\mathrm{GI}_{50}$ values $\left(\mu \mathrm{g} \mathrm{mL}{ }^{-1}\right)$.

\subsubsection{Antimicrobial activity}

The extracts $\left(0.10-20 \mathrm{mg} \mathrm{mL}^{-1}\right.$ in water) were tested against Bacillus cereus (food isolate), Staphylococcus aureus (ATCC 6538), Listeria monocytogenes (NCTC 7973), Escherichia coli (ATCC 25922), Enterobacter cloacae (ATCC 35030), and Salmonella typhimurium (ATCC 13311) by the microdilution and $p$-iodonitrotetrazolium violet methods (Heleno et al., 2013). Aspergillus fumigatus (ATCC 1022), Aspergillus ochraceus (ATCC 12066), Aspergillus niger (ATCC 6275), Penicillium ochrochloron (ATCC 9112), Penicillium funiculosum (ATCC 36839), and Penicillium verrucosum var. cyclopium (food isolate) were also tested. The Institute for Biological Research "Sinisa Stanković", Serbia, provided the microorganisms. Positive controls: streptomycin and ampicillin for the antibacterial activity; ketoconazole and bifonazole for the antifungal activity. The results were given as minimum inhibitory, bactericidal, and fungicidal concentrations (MIC, MBC, and MFC, respectively; $\mathrm{mg} \mathrm{mL}^{-1}$ ).

\subsection{Statistical analysis}

All experiments were performed in triplicate. Statistical tests were performed at a $5 \%$ significance level using SPSS Statistics (IBM SPSS Statistics for Windows, 22.0. Armonk, NY: IBM Corp.). Differences among samples were assessed by a Student's $t$-test (for the phenolic compounds content) or a one-way analysis of variance (ANOVA) (for the bioactivities).

\section{Results and discussion}

\subsection{Phenolic composition}

The phenolic profiles of the hydroethanolic extracts of in vitro-cultured E. viviparum aerial and root parts are shown in Fig. 1. Chromatographic data related to the compounds characterization process, tentative identities and contents are given in Table 1. Fourteen phenolic compounds were detected and grouped into phenolic acids (peaks 1-10) and flavonoids (peaks 11-14). Phenolic acids were the predominant compounds in both plant organs, with $38.3 \pm 0.8 \mathrm{mg} \mathrm{g}^{-1}$ and $102 \pm 4 \mathrm{mg} \mathrm{g}^{-1}$ of extract of aerial and root parts, respectively; while flavonoids were quantifiable just in the aerial part $\left(2.24 \pm 0.09 \mathrm{mg} \mathrm{g}^{-1}\right.$ extract).

Peak 9 was identified as trans rosmarinic acid based on its mass spectrum (Barros et al., 2013) with a pseudo molecular ion $[\mathrm{M}-\mathrm{H}]^{-}$at $\mathrm{m} / \mathrm{z} 359$ and fragment ions at $\mathrm{m} / \mathrm{z} 197,179$ and 161 (Table 1); its identity was set by comparison with the commercial standard. This phenolic acid was the major compound found in this endangered species, which corresponded to $71.4 \%$ and $78.7 \%$ of the total phenolic compounds quantified in aerial and root parts, respectively. Lower levels of rosmarinic acid than those found in the E. viviparum root have been reported in other Lamiaceae, such as rosemary (Rosmarinus 

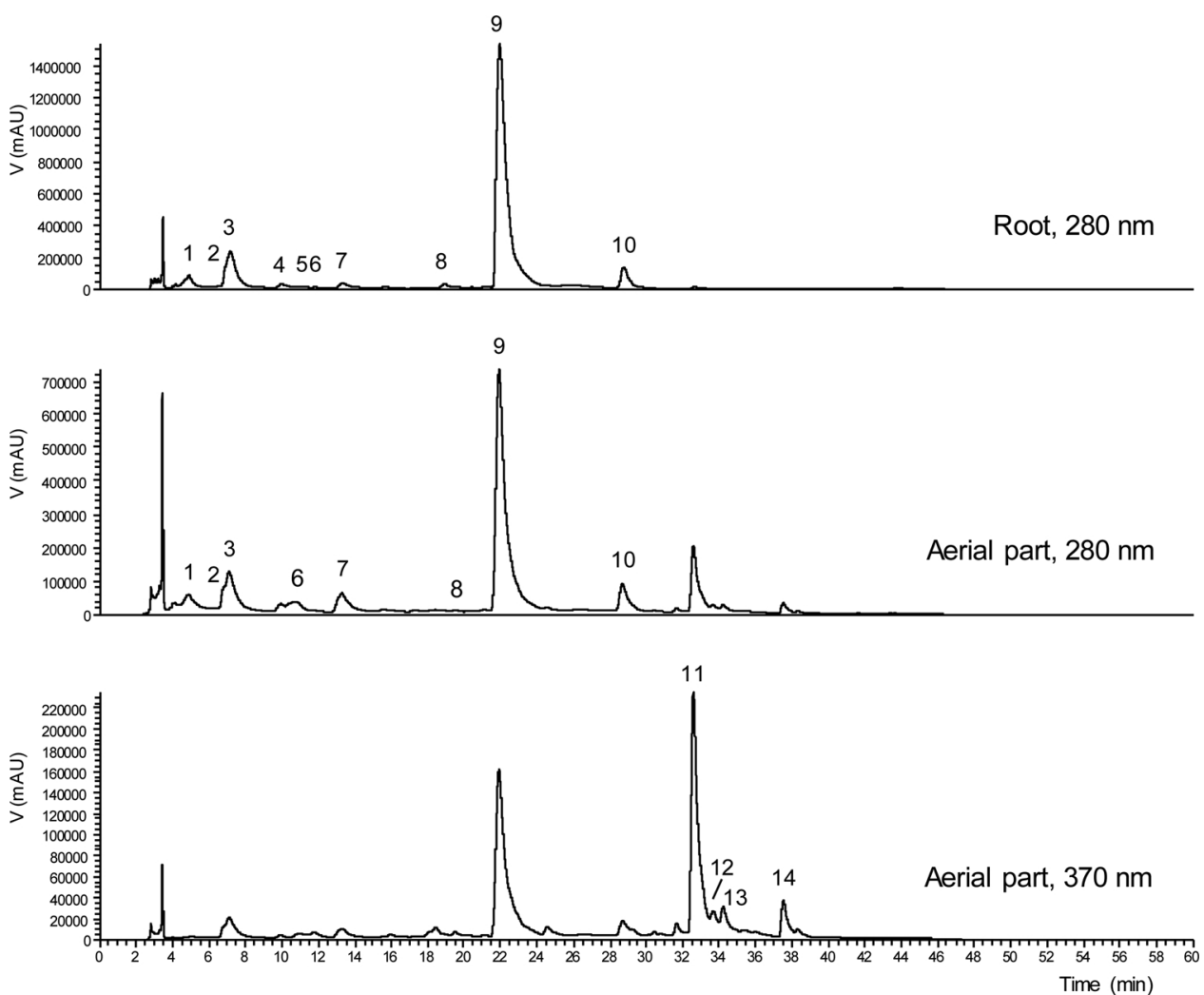

Fig. 1. HPLC phenolic profile of hydroethanolic extracts of in vitro cultured E. viviparum aerial and root parts. See Table 1 for peak identification.

officinalis L.; $6.9 \pm 0.2 \mathrm{mg} \mathrm{g}^{-1}$ extract; Gonçalves et al. (2019), and $68.5 \mathrm{mg} \mathrm{g}^{-1}$ extract; Ribeiro et al. (2016)) and spearmint (Mentha spicata L. $73.4 \pm 0.8 \mathrm{mg} \mathrm{g}^{-1}$ extract; Chrysargyris et al. (2019)).

Peak $1\left([\mathrm{M}-\mathrm{H}]^{-}\right.$at $m / z$ 197) was identified as $3-(3,4-$ dihydroxyphenyl)-lactic acid, also known as salvianic acid A or "Danshensu", based on its characteristic fragmentation pattern found in the literature (Zeng et al., 2006). Peak $4\left([\mathrm{M}-\mathrm{H}]^{-}\right.$at $\left.m / z 179\right)$ was identified as caffeic acid according to its retention time and UV-vis and

Table 1

Phenolic compounds identified and levels quantified in the hydroethanolic extracts of E. viviparum root and aerial part. It is presented the retention time (Rt), the wavelengths of maximum absorption in the visible region $\left(\lambda_{\max }\right)$, mass spectral data $\left(\mathrm{M}^{-} \mathrm{H}^{-}\right)$, and relative abundances of fragment ions $\left(\mathrm{MS}^{2}\right)$.

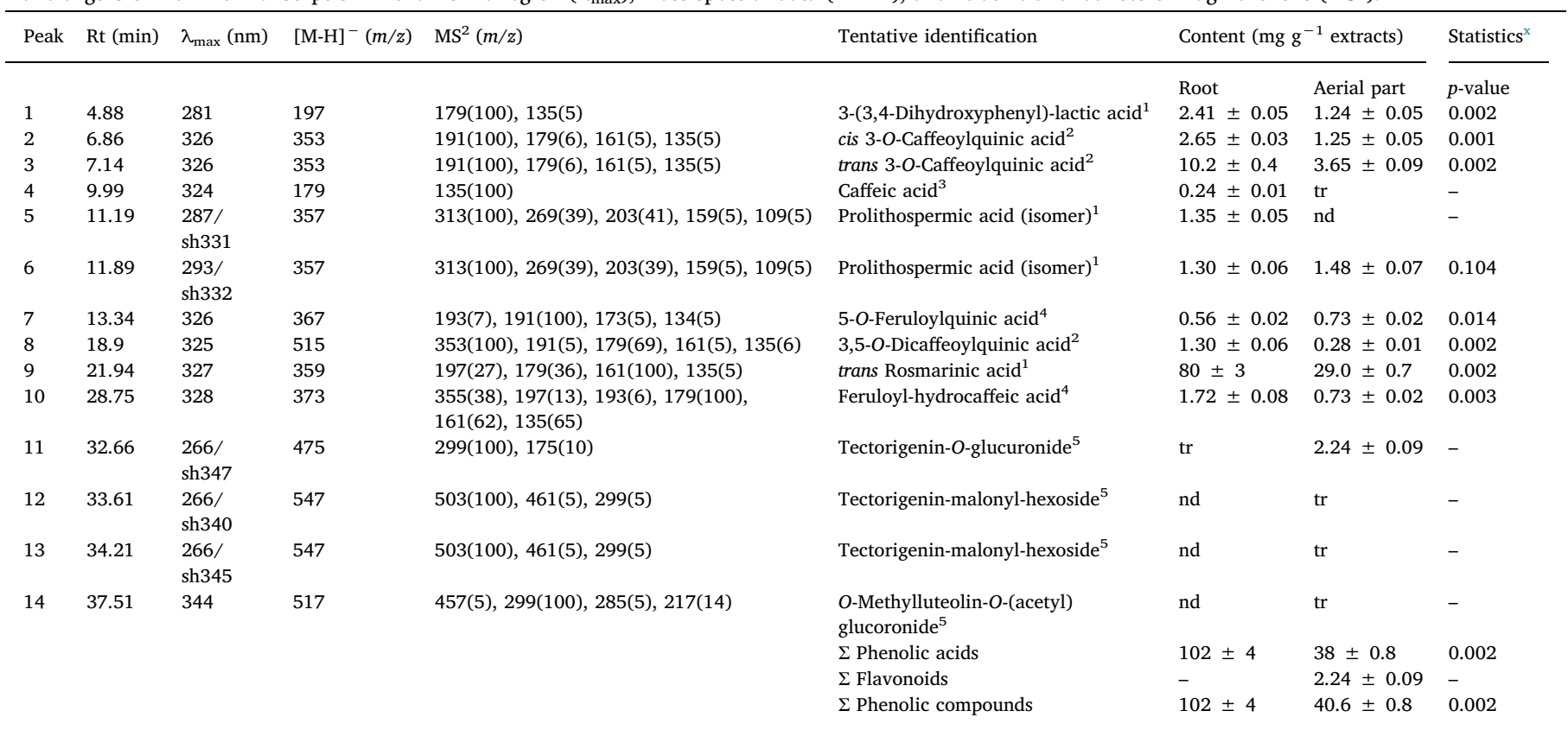

Standards used in the quantification: $\left({ }^{1}\right)$ - rosmarinic acid, $\left({ }^{2}\right)$ - chlorogenic acid, $\left({ }^{3}\right)$ - caffeic acid, $\left({ }^{4}\right)$ - ferulic acid, and $\left({ }^{5}\right)$ - quercetin-3-O-glucoside. tr: traces; nd: not detected.

${ }^{\mathrm{x}}$ A $t$-student test was applied to evaluate statistically significant differences $(p<0.05)$ between samples. 
mass characteristics in comparison with the commercial standard.

Peaks 2 and $3\left([\mathrm{M}-\mathrm{H}]^{-}\right.$at $\left.m / z 353\right)$ were identified as cis and trans 3-O-caffeoylquinic acid, respectively (Zheng et al., 2017), yielding the base peak at $m / z 191$ and ions at $m / z 179,161$ and 135. The trans isomer was the second most abundant quantified phenolic compounds, with aerial and root parts containing $3.65 \pm 0.09 \mathrm{mg} \mathrm{g}^{-1}$ and $10.2 \pm 0.4 \mathrm{mg} \mathrm{g}^{-1}$ of extract, respectively.

Both rosmarinic and caffeoylquinic acids were previously reported as the main phenolic acids found in Eryngium spp. (Kikowska et al., 2014; Vukic et al., 2018). Rosmarinic acid is a well-known antioxidant with several biological properties, including antibacterial, antiviral, anti-inflammatory, antidiabetic, and anticarcinogenic activities and neuroprotective and cardioprotective effects (Nabavi et al., 2015; Nunes et al., 2015). This compound has major structural features that may contribute to the in vitro activities, including a $\mathrm{OH}$ group, two phenol $-\mathrm{OH}$ groups, a $\mathrm{C}-\mathrm{C}$ bond, an alkoxy group, and an ester moiety (Taguchi et al., 2017).

Peaks 5 and $6\left([\mathrm{M}-\mathrm{H}]^{-}\right.$at $m / z$ 357) were identified as prolithospermic acid isomers (Grzegorczyk-Karolak et al., 2018), a product of salvianolic acid B degradation often found in the Lamiaceae family (Fecka et al., 2007; Zhou et al., 2011). Peak 7 ([M-H $]^{-}$at $\mathrm{m} / z$ 367) and peak $8\left([\mathrm{M}-\mathrm{H}]^{-}\right.$at $\left.\mathrm{m} / \mathrm{z} 515\right)$ were assigned as 5 -O-feruloylquinic acid and 3,5-O-dicaffeoylquinic acid, respectively (Guimarães et al., 2013b).

Regarding flavonoids, a glucuronide-conjugated of tectorigenin, tectorigenin- $O$-glucuronide ([M-H $]^{-}$at $\left.m / z 475\right)$, was identified in both organs of E. viviparum, being particularly abundant in the aerial part $\left(2.24 \pm 0.09 \mathrm{mg} \mathrm{g}^{-1}\right.$ extract); only a trace amount was detected in the root extract. Tectorigenin was previously reported in flowers of Pueraria thomsonii Benth. and rhizomes of Belamcanda chinensis (L.) DC. (Wang et al., 2013). According to Applová et al. (2017), this isoflavone is a more potent antiplatelet compound than acetylsalicylic acid. It has also been shown to exert anti-proliferative effects on tumour cells (Thelen et al., 2005). To the best of the authors' knowledge, this is the first study reporting the presence of tectorigenin in Eryngium and Apiaceae spp.

Traces of tectorigenin-malonyl-hexoside (peaks 12 and 13) and $O$ methylluteolin-O-(acetyl)glucoronide (peak 14) were detected just in the aerial part of $E$. viviparum.

\subsection{In vitro biological activities}

\subsubsection{Antioxidant activity}

The results of the two antioxidant activity assays performed with the extracts of aerial and root parts of E. viviparum are presented in Table 2. For the OxHLIA assay, it is given the extract concentration required to protect $50 \%$ of the erythrocytes from the haemolysis induced by the hydrophilic free radical initiator AAPH for 30 and $60 \mathrm{~min}$. In addition, $\mathrm{IC}_{50}$ values are given at two $\Delta t$, as natural extracts contain a wide range of antioxidant compounds capable of offering protection at different time periods (Lockowandt et al., 2019). For the TBARS assay, it is given the extract concentration required to provide $50 \%$ of antioxidant activity, in other words, the dose at which the extracts can avoid the formation of malondialdehyde through the $\mathrm{H}$ donation to lipid radicals. Hence, in both assays, the lower the $\mathrm{IC}_{50}$, the higher the antioxidant activity of the tested extracts.

As observed in Table 2, the antioxidant activity of the root extract was higher than that of the aerial part of $E$. viviparum. In TBARS, the $\mathrm{IC}_{50}$ value achieved with root extract $\left(14.9 \pm 0.3 \mu \mathrm{g} \mathrm{mL}{ }^{-1}\right)$ was just 2.8 -fold higher than that of trolox $\left(5.4 \pm 0.3 \mu \mathrm{g} \mathrm{mL} \mathrm{m}^{-1}\right)$, while the aerial part extract was 4.7 -fold less effective than this synthetic antioxidant. However, it is interesting to note that trolox is a pure antioxidant compound, while plant extracts are complex mixtures of different phytochemicals with or without bioactive properties. In OxHLIA, $68 \pm 3 \mu \mathrm{g} \mathrm{mL}^{-1}$ and $141 \pm 6 \mu \mathrm{g} \mathrm{mL}{ }^{-1}$ of root extract were needed to protect $50 \%$ of the erythrocyte population for $30 \mathrm{~min}$ and $60 \mathrm{~min}$, respectively. This extract was $2.6 \%$ more effective than the one of the aerial part at both given $\Delta t$. Comparing with trolox, it can also be concluded that the $E$. viviparum extracts were more effective at $60 \mathrm{~min}$ than at $30 \mathrm{~min}$. These results can be linked to the higher content of bioactive phenolic compounds, such as rosmarinic and caffeoylquinic acids, detected in the root of the studied endangered plant (Table 1), since polyphenols have the capacity to donate $\mathrm{H}^{+}$and $\mathrm{e}^{-}$to free radicals, stabilizing them and giving rise to a quite stable phenolic radical (Heim et al., 2002).

To the best of authors' knowledge, this is the first study reporting the in vitro antioxidant activity of E. viviparum extracts, but there are reports with other Eryngium spp. including E. serbicum L. (Vukic et al., 2018), E. bourgatii (Cádiz-Gurrea et al., 2013), and E. maritimum (Mejri et al., 2017).

\subsubsection{Cytotoxic activity}

The results of the cytotoxic activity of E. viviparum extracts against four human tumour cells and a non-tumour porcine liver cell culture are displayed in Table 2. These are given as $\mathrm{GI}_{50}$ values, which correspond to the extract dose needed to inhibit $50 \%$ of cell growth. Hepatocellular carcinoma HepG2 was the most sensitive tumour cell line to both $E$. viviparum extracts $\left(\mathrm{GI}_{50}=239 \mu \mathrm{g} \mathrm{mL} \mathrm{m}^{-1}\right)$. The root extract was also cytotoxic to the cell lines NCI-H460 (non-small cell lung carcinoma) and MCF-7 (breast adenocarcinoma), with $\mathrm{GI}_{50}$ values of $305 \pm 10 \mu \mathrm{g}$ $\mathrm{mL}^{-1}$ and $350 \pm 12 \mu \mathrm{gL}^{-1}$, respectively. On the other hand, none of the extracts was cytotoxic to HeLa cells (cervical carcinoma) or hepatotoxic to the normal PLP2 cells at the tested concentrations $\left(\mathrm{GI}_{50}>400 \mu \mathrm{g} \mathrm{mL}^{-1}\right)$. Ellipticine, a potent antineoplastic agent used as positive control, revealed significantly higher cytotoxicity to the human tumour cells than E. viviparum extracts, but also to the non-tumour cell line. Once again, these results may be linked to the higher level of bioactive polyphenols detected in the root (Table 1).

Extracts or isolates from Eryngium spp. have been described to have cytotoxic activity against tumour cells (Wang et al., 2012). Monks et al.

Table 2

Antioxidant and cytotoxic activities of E. viviparum extracts and positive controls.

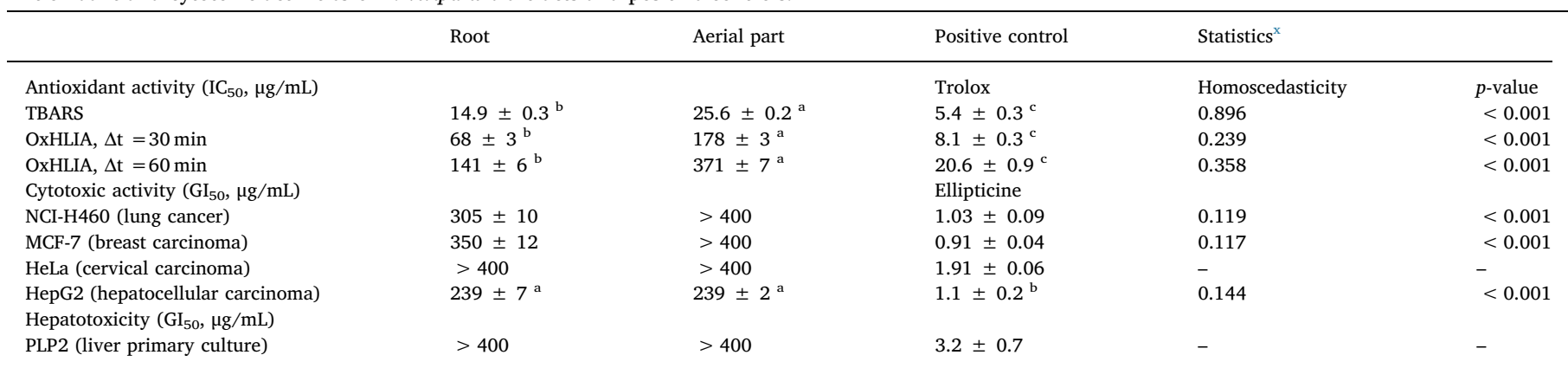

${ }^{\mathrm{x}}$ Statistically significant differences $(p<0.05)$ between three or two variables were assessed by a one-way ANOVA, using the Tukey's HSD test for homoscedastic samples $(p>0.05)$, or by a Student's $t$-test, respectively. 
Table 3

Antimicrobial activity of E. viviparum extracts and positive controls.

\begin{tabular}{|c|c|c|c|c|c|c|c|c|}
\hline & \multicolumn{2}{|l|}{ Root } & \multicolumn{2}{|c|}{ Aerial part } & \multicolumn{4}{|c|}{ Positive control } \\
\hline \multicolumn{3}{|c|}{ Antibacterial activity } & & & \multicolumn{2}{|c|}{ Streptomycin } & \multicolumn{2}{|c|}{ Ampicillin } \\
\hline & MIC & MBC & MIC & MBC & MIC & MBC & MIC & MBC \\
\hline B. cereus & 1 & 2 & 2 & 4 & 0.1 & 0.2 & 0.25 & 0.4 \\
\hline S. aureus & 4 & 8 & 4 & 8 & 0.04 & 0.1 & 0.25 & 0.45 \\
\hline L. monocytogenes & 2 & 4 & 2 & 4 & 0.2 & 0.3 & 0.4 & 0.5 \\
\hline E. coli & 1 & 2 & 2 & 4 & 0.2 & 0.3 & 0.4 & 0.5 \\
\hline E. cloacae & 2 & 4 & 2 & 4 & 0.2 & 0.3 & 0.25 & 0.5 \\
\hline S. typhimurium & 2 & 4 & 0.5 & 1 & 0.2 & 0.3 & 0.75 & 1.2 \\
\hline \multicolumn{5}{|l|}{ Antifungal activity } & \multicolumn{2}{|c|}{ Ketoconazole } & \multicolumn{2}{|c|}{ Bifonazole } \\
\hline & MIC & MFC & MIC & MFC & MIC & MFC & MIC & MFC \\
\hline A. fumigatus & 1 & 2 & 8 & 16 & 0.25 & 0.5 & 0.15 & 0.2 \\
\hline A. ochraceus & 1 & 2 & 4 & 8 & 0.2 & 0.5 & 0.1 & 0.2 \\
\hline A. niger & 4 & 8 & 8 & 16 & 0.2 & 0.5 & 0.15 & 0.2 \\
\hline P. funiculosum & 0.5 & 1 & 2 & 4 & 0.2 & 0.5 & 0.2 & 0.25 \\
\hline P. ochrochloron & 1 & 2 & 4 & 8 & 2.5 & 3.5 & 0.2 & 0.25 \\
\hline P. verrucosum & 0.5 & 1 & 2 & 4 & 0.2 & 0.3 & 0.1 & 0.2 \\
\hline
\end{tabular}

MIC: minimal inhibitory concentration ( $\mathrm{mg} \mathrm{mL}^{-1}$ ); MBC: minimal bactericidal concentration ( $\mathrm{mg} \mathrm{mL}{ }^{-1}$ ); MFC: minimum fungicidal concentration (mg $\mathrm{mL}^{-1}$ ).

(2002) described E. ebracteatum leaf and root organic extracts and $E$. nudicale aerial part aqueous extracts as having cytotoxic effects to NCIH460. Paşayeva et al. (2017) described E. creticum aqueous extracts and E. billardieri methanolic extracts as capable of inhibiting MCF-7 cell growth (Paşayeva et al., 2017). Furthermore, Yurdakök and Baydan (2013) also reported cytotoxicity of $E$. kotschyi and E. maritimum aqueous extracts from aerial and root parts against HepG2 cells (Yurdakök and Baydan, 2013).

\subsubsection{Antimicrobial activity}

The results of the antimicrobial activity of $E$. viviparum extracts are presented in Table 3. In general, the Gram-negative bacteria were more sensitive to the tested extracts. Bacillus cereus and E. coli were the most susceptible bacteria to the root extract (MIC $=1 \mathrm{mg} \mathrm{mL}^{-1}$ and $\mathrm{MBC}=2 \mathrm{mg} \mathrm{mL}^{-1}$ ), which in general gave the best results. Salmonella typhimurium was the only microorganism to have greater sensitivity to the extract of aerial part and the one presenting the lowest MICs $\left(0.5 \mathrm{mg} \mathrm{mL}^{-1}\right)$ and MBCs $\left(1 \mathrm{mg} \mathrm{mL}^{-1}\right)$; interestingly, the MIC obtained for this enteric pathogen was lower than that of the positive control ampicillin $\left(0.75 \mathrm{mg} \mathrm{mL}^{-1}\right)$. For $S$. aureus and L. monocytogenes, the MICs and MBCs obtained with the root extract were the same as those obtained with the aerial part.

The root extract also provided the best antifungal activity (Table 3), with MICs and MBCs between $0.5-4 \mathrm{mg} \mathrm{mL}^{-1}$ and $1-8 \mathrm{mg} \mathrm{mL}^{-1}$, respectively. A. niger and $A$. fumigatus were the most resistant fungi to the tested $E$. viviparum extracts. In turn, $P$. funiculosum and $P$. verrucosum var. cyclopium were the most susceptible to the tested extracts, being required $0.5 \mathrm{mg} \mathrm{mL}^{-1}$ and $1 \mathrm{mg} \mathrm{mL}^{-1}$ of root extract and $2 \mathrm{mg} \mathrm{mL}^{-1}$ and $4 \mathrm{mg} \mathrm{mL}^{-1}$ of aerial part extract to inhibit or kill these two microorganisms. Interestingly, the root extract was more effective than ketoconazole in inhibiting and killing $P$. ochrochloron. As mentioned above, caffeic acid derivatives have many biological actives, including antimicrobial effects (Nabavi et al., 2015; Nunes et al., 2015), and could be linked to the observed effect.

Extracts of Eryngium spp. have shown a broad antimicrobial activity against a number of bacteria and fungi (Erdem et al., 2015). E. maritimum, E. planum and E. campestre hydroethanolic extracts (Thiem et al., 2010) and the apolar fraction of a methanol-chloroform-water extract of E. maritimum (Meot-Duros et al., 2008) revealed antibacterial activity against $B$. cereus and $S$. aureus and antifungal activity against $A$. niger. Methanolic and chloroform extracts of $E$. palmatum leaves and roots also showed activity against $S$. aureus and $E$. coli (Marčetić et al., 2014). In addition, fractions of methanolic extracts obtained from $E$. caeruleum aerial parts were effective against E. coli, S. typhimurium, A. fumigatus, and A. niger (Sadiq et al., 2016). However, to the best of the authors' knowledge, this is the first report on Eryngium extracts with antibacterial activity against Enterobacter and Listeria strain and antifungal activity against Penicillium genus.

\section{Conclusion}

In this study, the in vitro cultured E. viviparum plant was characterized as an interesting source of phenolic acids, particularly rosmarinic and trans 3-O-caffeoylquinic acids, which were particularly abundant in the root. Flavonoids were quantified just in the aerial part. The root extract showed the highest antioxidant activity, especially in the TBARS assay, and cytotoxicity to the NCI-H460 (non-small cell lung carcinoma), MCF-7 (breast adenocarcinoma), and HepG2 (hepatocellular carcinoma) cell lines. On the other hand, none of the extracts was cytotoxic to non-tumour primary PLP2 cells up to the concentration of $400 \mu \mathrm{g} / \mathrm{mL}$. In general, the root extract also provided better antimicrobial activity than the aerial part extract. Bacillus cereus and E. coli were the most susceptible bacteria to this extract, while $P$. funiculosum and $P$. verrucosum var. cyclopium were the most susceptible fungi. Interestingly, the root extract was more effective than ketoconazole against $P$. ochrochloron, whereas $S$. typhimurium was the only microorganism to have greater sensitivity to the extract of the aerial part, with a MIC lower than that of ampicillin. Therefore, this study promotes the interest of conserving E. viviparum given its content in phenolic acids with antioxidant and antimicrobial properties, which can be exploited by different industrial sectors interested in bio-based ingredients.

\section{CRediT authorship contribution statement}

Manuel Ayuso: Methodology, Investigation, Formal analysis, Writing - original draft. José Pinela: Methodology, Investigation, Formal analysis, Writing - original draft, Writing - review \& editing. Maria Inês Dias: Methodology, Investigation. Lillian Barros: Conceptualization, Methodology, Formal analysis, Project administration, Writing - original draft, Writing - review \& editing. Marija Ivanov: Methodology, Investigation. Ricardo C. Calhelha: Methodology. Marina Soković: Methodology, Investigation. Pablo Ramil-Rego: Funding acquisition, Project administration. M. Esther Barreal: Conceptualization, Investigation. Pedro Pablo Gallego: Conceptualization, Funding acquisition, Project administration, Writing - review \& editing. Isabel C.F.R. Ferreira: Conceptualization, Methodology, Formal analysis, Funding acquisition, Project administration, Writing - review \& editing.

\section{Declaration of Competing Interest}

The authors declare that they have no known competing financial interests or personal relationships that could have appeared to influence the work reported in this paper.

\section{Acknowledgements}

The authors are grateful to the Foundation for Science and Technology (FCT, Portugal) for financial support through national funds FCT/MCTES to CIMO (UIDB/00690/2020) and the research contracts of J. Pinela, M.I. Dias, R.C. Calhelha, and L. Barros (national funding by FCT, P.I., through the institutional scientific employment program-contract). To the FEDER-Interreg España-Portugal programme for financial support through the project 0377_Iberphenol_6_E. To the project TRANSCoLAB: 0612_TRANS_CO_LAB_2_P. This work was also supported by Xunta de Galicia, Spain (CITACA Strategic Partnership, Reference: ED431E 2018/07), "Red de Uso Sostenible de Recursos y Residuos" (ED431D 2017/18), and the Research Stay Grant of Manuel Ayuso from IACOBUS program. 


\section{References}

Aguiar, C., 2003. O Eryngium viviparum gay. Afinal não está extinto em Portugal. Silva Lusitana. Estação Florestal Nacional, Bragança, pp. 231-232.

Applová, L., Karlíčková, J., Říha, M., Filipský, T., Macáková, K., Spilková, J., Mladěnka, P., 2017. The isoflavonoid tectorigenin has better antiplatelet potential than acetylsalicylic acid. Phytomedicine 35, 11-17.

Atanasov, A.G., Waltenberger, B., Pferschy-Wenzig, E.-M., Linder, T., Wawrosch, C., Uhrin, P., Temml, V., Wang, L., Schwaiger, S., Heiss, E.H., Rollinger, J.M., Schuster, D., Breuss, J.M., Bochkov, V., Mihovilovic, M.D., Kopp, B., Bauer, R., Dirsch, V.M. Stuppner, H., 2015. Discovery and resupply of pharmacologically active plant-derived natural products: a review. Biotechnol. Adv. 33, 1582-1614. https://doi.org/ 10.1016/J.BIOTECHADV. 2015.08.001.

Ayuso, M., Ramil-Rego, P., Landin, M., Gallego, P.P., Barreal, M.E., 2017. Computerassisted recovery of threatened plants: Keys for breaking seed dormancy of Eryngium viviparum. Front. Plant Sci. 8, 2092. https://doi.org/10.3389/fpls.2017.02092.

Ayuso, M., García-Pérez, P., Ramil-Rego, P., Gallego, P.P., Barreal, M.E., 2019. In vitro culture of the endangered plant Eryngium viviparum as dual strategy for its ex situ conservation and source of bioactive compounds. Plant Cell Tissue Organ Cult. 138, 427-435. https://doi.org/10.1007/s11240-019-01638-y.

Bañares, A., Blanca, G., Güemes, J., Moreno, J., Ortiz, S., 2004. Atlas y Libro Rojo de la Flora Vascular Amenazada de España. Dirección General de Conservación de la Naturaleza, Madrid.

Barros, L., Dueñas, M., Dias, M.I., Sousa, M.J., Santos-Buelga, C., Ferreira, I.C.F.R., 2013. Phenolic profiles of cultivated, in vitro cultured and commercial samples of Melissa officinalis L. infusions. Food Chem. 136, 1-8. https://doi.org/10.1016/J.FOODCHEM 2012.07.107.

Belkaid, A., Currie, J.-C., Desgagnés, J., Annabi, B., 2006. The chemopreventive properties of chlorogenic acid reveal a potential new role for the microsomal glucose-6phosphate translocase in brain tumor progression. Cancer Cell Int. 6, 7. https://doi org /10.1186/1475-2867-6-7.

Bessada, S.M.F., Barreira, J.C.M., Barros, L., Ferreira, I.C.F.R., Oliveira, M.B.P.P., 2016 Phenolic profile and antioxidant activity of Coleostephus myconis (L.) Rchb.f.: an underexploited and highly disseminated species. Ind. Crops Prod. 89, 45-51.

Cádiz-Gurrea, M., de la, L., Fernández-Arroyo, S., Joven, J., Segura-Carretero, A., 2013. Comprehensive characterization by UHPLC-ESI-Q-TOF-MS from an Eryngium bourgatii extract and their antioxidant and anti-inflammatory activities. Food Res. Int. 50, 197-204. https://doi.org/10.1016/J.FOODRES.2012.09.038.

Chrysargyris, A., Petropoulos, S.A., Fernandes, Â., Barros, L., Tzortzakis, N., Ferreira I.C.F.R., 2019. Effect of phosphorus application rate on Mentha spicata L. grown in deep flow technique (DFT). Food Chem. 276, 84-92. https://doi.org/10.1016/j. foodchem.2018.10.020.

Dias, M.I., Sousa, M.J., Alves, R.C., Ferreira, I.C.F.R., 2016. Exploring plant tissue culture to improve the production of phenolic compounds: a review. Ind. Crops Prod. 82, 9-22. https://doi.org/10.1016/J.INDCROP.2015.12.016.

Engelmann, F., 2011. Use of biotechnologies for the conservation of plant biodiversity. Vitr. Cell. Dev. Biol. - Plant 47, 5-16. https://doi.org/10.1007/s11627-010-9327-2.

Erdem, S.A., Nabavi, S.F., Orhan, I.E., Daglia, M., Izadi, M., Nabavi, S.M., 2015. Blessings in disguise: a review of phytochemical composition and antimicrobial activity of plants belonging to the genus Eryngium. Daru J. Fac. Pharmacy, Tehran Univ. Med. Sci. 23, 23-53.

Fecka, I., Raj, D., Krauze-Baranowska, M., 2007. Quantitative determination of four water-soluble compounds in herbal drugs from Lamiaceae using different chromatographic techniques. Chromatographia 66, 87-93. https://doi.org/10.1365/s10337007-0233-7.

Gonçalves, G.A., Corrêa, R.C.G., Barros, L., Dias, M.I., Calhelha, R.C., Correa, V.G., Bracht, A., Peralta, R.M., Ferreira, I.C.F.R., 2019. Effects of in vitro gastrointestinal digestion and colonic fermentation on a rosemary (Rosmarinus officinalis L.) extract rich in rosmarinic acid. Food Chem. 271, 393-400. https://doi.org/10.1016/j. foodchem.2018.07.132.

Grzegorczyk-Karolak, I., Kuźma, Ł., Skała, E., Kiss, A.K., 2018. Hairy root cultures of Salvia viridis L. For production of polyphenolic compounds. Ind. Crops Prod. 117, 235-244. https://doi.org/10.1016/J.INDCROP.2018.03.014.

Gugliucci, A., Bastos, D.H.M., 2009. Chlorogenic acid protects paraoxonase 1 activity in high density lipoprotein from inactivation caused by physiological concentrations of hypochlorite. Fitoterapia 80, 138-142. https://doi.org/10.1016/J.FITOTE.2009.01. 001.

Guimarães, R., Barros, L., Dueñas, M., Calhelha, R.C., Carvalho, A.M., Santos-Buelga, C., Queiroz, M.J.R.P., Ferreira, I.C.F.R., 2013a. Nutrients, phytochemicals and bioactivity of wild Roman chamomile: a comparison between the herb and its preparations. Food Chem. 136, 718-725. https://doi.org/10.1016/j.foodchem.2012.08.025.

Guimarães, R., Barros, L., Dueñas, M., Calhelha, R.C., Carvalho, A.M., Santos-Buelga, C., Queiroz, M.J.R.P., Ferreira, I.C.F.R., 2013b. Infusion and decoction of wild German chamomile: bioactivity and characterization of organic acids and phenolic compounds. Food Chem. 136, 947-954. https://doi.org/10.1016/J.FOODCHEM.2012. 09.007.

Heim, K.E., Tagliaferro, A.R., Bobilya, D.J., 2002. Flavonoid antioxidants: chemistry, metabolism and structure-activity relationships. J. Nutr. Biochem. 13, 572-584. https://doi.org/10.1016/S0955-2863(02)00208-5.

Heleno, S.A., Ferreira, I.C.F.R., Esteves, A.P., Ćirić, A., Glamočlija, J., Martins, A. Soković, M., Queiroz, M.J.R.P., 2013. Antimicrobial and demelanizing activity of Ganoderma lucidum extract, $p$-hydroxybenzoic and cinnamic acids and their synthetic acetylated glucuronide methyl esters. Food Chem. Toxicol. 58, 95-100.

Kikowska, M., Thiem, B., Sliwinska, E., Rewers, M., Kowalczyk, M., Stochmal, A., Oleszek, W., 2014. The effect of nutritional factors and plant growth regulators on micropropagation and production of phenolic acids and saponins from plantlets and adventitious root cultures of Eryngium maritimum L. J. Plant Growth Regul. 33, 809-819. https://doi.org/10.1007/s00344-014-9428-y.

Lansdown, R., 2011. Eryngium viviparum. In: Walter, K., Gillett, H. (Eds.), The IUCN Red List of Threatened Species 2011. The World Conservation Monitoring Center. IUCN The World Conservation Union, Cambridge, pp. 862. https://doi.org/10.2305/IUCN. UK.2011-1.RLTS.T161835A5502083.

Lavergne, S., Thuiller, W., Molina, J., Debussche, M., 2005. Environmental and human factors influencing rare plant local occurrence, extinction and persistence: a 115-year study in the Mediterranean region. J. Biogeogr. 32, 799-811. https://doi.org/10. 1111/j.1365-2699.2005.01207.x.

Li, J.W.-H., Vederas, J.C., 2009. Drug discovery and natural products: End of an era or an endless frontier? Science 325 (80-), 161-165.

Lockowandt, L., Pinela, J., Roriz, C.L., Pereira, C., Abreu, R.M.V., Calhelha, R.C., Alves, M.J., Barros, L., Bredol, M., Ferreira, I.C.F.R., 2019. Chemical features and bioactivities of cornflower (Centaurea cyanus L.) capitula: the blue flowers and the unexplored non-edible part. Ind. Crops Prod. 128, 496-503.

Marčetić, M., Petrović, S., Milenković, M., Niketić, M., 2014. Composition, antimicrobial and antioxidant activity of the extracts of Eryngium palmatum Pančić and Vis. Apiaceae). Open Life Sci. 9, 149-155. https://doi.org/10.2478/s11535-013-0247-0.

Mejri, H., Tir, M., Feriani, A., Ghazouani, L., Salah Allagui, M., Saidani-Tounsi, M., 2017. Does Eryngium maritimum seeds extract protect against $\mathrm{CCl} 4$ and cisplatin induced toxicity in rats: preliminary phytochemical screening and assessment of its in vitro and in vivo antioxidant activity and antifibrotic effect. J. Funct. Foods 37, 363-372. https://doi.org/10.1016/J.JFF.2017.07.054.

Meot-Duros, L., Le Floch, G., Magné, C., 2008. Radical scavenging, antioxidant and antimicrobial activities of halophytic species. J. Ethnopharmacol. 116, 258-262. https://doi.org/10.1016/J.JEP.2007.11.024.

Monks, N.R., Bordignon, S.A.L., Ferraz, A., Machado, K.R., Faria, D.H., Lopes, R.M., Mondin, C.A., Souza, I.C.C., Lima, M.F.S., da Rocha, A.B., Schwartsmann, G., 2002. Anti-tumour screening of brazilian plants. Pharm. Biol. 40, 603-616. https://doi.org/ 10.1076/phbi.40.8.603.14658.

Murashige, T., Skoog, F., 1962. A revised medium for rapid growth and bio assays with tobacco tissue cultures. Physiol. Plant. 15, 473-497. https://doi.org/10.1111/j.13993054.1962.tb08052.x.

Nabavi, S.F., Tenore, G.C., Daglia, M., Tundis, R., Loizzo, M.R., Nabavi, S.M., 2015. The cellular protective effects of rosmarinic acid: from bench to bedside. Curr. Neurovasc. Res. 12, 98-105.

Nunes, S., Madureira, R., Campos, D., Sarmento, B., Gomes, A.M., Pintado, M., Reis, F., 2015. Therapeutic and nutraceutical potential of rosmarinic acid - Cytoprotective properties and pharmacokinetic profile. Crit. Rev. Food Sci. Nutr. 57 00-00.

Paşayeva, L., Köngül, E., Geylan, R., Karatoprak, G.Ş., Tugay, O., Paşayeva, L., Köngül, E., Geylan, R., Karatoprak, G.S., Tugay, O., 2017. Analysis of the cytotoxic effects of Eryngium billardieri Delar. Extracts on MCF7 cell line. Proceedings 1, 1055. https:// doi.org/10.3390/proceedings1101055.

Petersen, M., Simmonds, M.S., 2003. Rosmarinic acid. Phytochemistry 62, 121-125. https://doi.org/10.1016/S0031-9422(02)00513-7.

Rascle, P., Bioret, F., Magnanon, S., Glemarec, E., Gautier, C., Guillevic, Y., Gallet, S., 2018. Identification of success factors for the reintroduction of the critically endangered species Eryngium viviparum J. Gay (Apiaceae). Ecol. Eng. 122, 112-119.

Ribeiro, A., Caleja, C., Barros, L., Santos-Buelga, C., Barreiro, M.F., Ferreira, I.C.F.R. 2016. Rosemary extracts in functional foods: extraction, chemical characterization and incorporation of free and microencapsulated forms in cottage cheese. Food Funct. 7, 2185-2196. https://doi.org/10.1039/c6fo00270f.

Romero, M., Ramil-Rego, P., Rubinos, M., 2004. Conservation status of Eryngium viviparum Gay. Acta Bot. Gall. 151, 55-64.

Sadiq, A., Ahmad, Sadiq, Ali, R., Ahmad, F., Ahmad, Sajjad, Zeb, A., Ayaz, M., Ullah, F., Siddique, A.N., 2016. Antibacterial and antifungal potentials of the solvents extracts from Eryngium caeruleum, Notholirion thomsonianum and Allium consanguineum. BMC Complement. Altern. Med. 16, 478. https://doi.org/10.1186/s12906-016-1465-6.

Sarasan, V., Cripps, R., Ramsay, M.M., Atherton, C., McMichen, M., Prendergast, G., Rowntree, J.K., 2006. Conservation in vitro of threatened plants - Progress in the past decade. Vitr. Cell. Dev. Biol. - Plant 42, 206-214. https://doi.org/10.1079/ IVP2006769.

Taguchi, R., Hatayama, K., Takahashi, T., Hayashi, T., Sato, Y., Sato, D., Ohta, K., Nakano, H., Seki, C., Endo, Y., Tokuraku, K., Uwai, K., 2017. Structure-activity relations of rosmarinic acid derivatives for the amyloid $\beta$ aggregation inhibition and antioxidant properties. Eur. J. Med. Chem. 138, 1066-1075. https://doi.org/10.1016/j.ejmech. 2017.07.026.

Thelen, P., Scharf, J.-G., Burfeind, P., Hemmerlein, B., Wuttke, W., Spengler, B., Christoffel, V., Ringert, R.-H., Seidlová-Wuttke, D., 2005. Tectorigenin and other phytochemicals extracted from leopard lily Belamcanda chinensis affect new and established targets for therapies in prostate cancer. Carcinogenesis 26, 1360-1367. https://doi.org/10.1093/carcin/bgi092.

Thiem, B., Goslinska, O., Kikowska, M., Budzianowski, J., 2010. Antimicrobial activity of three Eryngium L. species (Apiaceae). Herba Pol. 56, 52-59.

Vukic, M.D., Vukovic, N.L., Djelic, G.T., Obradovic, A., Kacaniova, M.M., Markovic, S., Popović, S., Baskić, D., 2018. Phytochemical analysis, antioxidant, antibacterial and cytotoxic activity of different plant organs of Eryngium serbicum L. Ind. Crops Prod. $115,88-97$.

Wang, P., Su, Z., Yuan, W., Deng, G., Li, S., 2012. Phytochemical constituents and pharmacological activities of Eryngium L. (Apiaceae). Pharm. Crop. 3, 99-120.

Wang, S., Gong, T., Lu, J., Kano, Y., Yuan, D., 2013. Simultaneous determination of tectorigenin and its metabolites in rat plasma by ultra performance liquid chromatography/quadrupole time-of-flight mass spectrometry. J. Chromatogr. B 933, 50-58.

Yurdakök, B., Baydan, E., 2013. Cytotoxic effects of Eryngium kotschyi and Eryngium 
maritimum on Hep2, HepG2, Vero and U138 MG cell lines. Pharm. Biol. 51, 1579-1585. https://doi.org/10.3109/13880209.2013.803208.

Zeng, G., Xiao, H., Liu, J., Liang, X., 2006. Identification of phenolic constituents in Radix salvia miltiorrhizae by liquid chromatography/electrospray ionization mass spectrometry. Rapid Commun. Mass Spectrom. 20, 499-506.

Zheng, X., Renslow, R.S., Makola, M.M., Webb, I.K., Deng, L., Thomas, D.G., Govind, N., Ibrahim, Y.M., Kabanda, M.M., Dubery, I.A., Heyman, H.M., Smith, R.D., Madala,
N.E., Baker, E.S., 2017. Structural elucidation of cis/trans dicaffeoylquinic acid photoisomerization using ion mobility spectrometry-mass spectrometry. J. Phys. Chem. Lett. 8, 1381-1388. https://doi.org/10.1021/acs.jpclett.6b03015.

Zhou, L.-N., Zhang, X., Xu, W.-Z., Ma, X.-N., Jia, Z., Zheng, Y.-M., You, S., 2011. Studies on the stability of salvianolic acid B as potential drug material. Phytochem. Anal. 22, 378-384. https://doi.org/10.1002/pca.1291. 